\title{
Laboratory Experiences for Prospective Science Teachers: A Meta-analytic Review of Issues and Concerns
}

\author{
Shashi Prabha, PhD \\ National Council of Educational Research and Training, New Delhi, India \\ doi: 10.19044/esj.2016.v12n34p235 URL:http://dx.doi.org/10.19044/esj.2016.v12n34p235
}

\begin{abstract}
Prospective science teachers need to be prepared for making laboratory experiences integral part of teaching-learning of science in order to facilitate students to nurture their natural curiosity. This can engage students towards acquiring proficiency in the processes that can lead them to inquiry and generation and validation of scientific knowledge. This study is guided by the research question, "what is the status of laboratory experiences for prospective teachers?" and "what is missing in prospective science teachers' preparation programme in order to bring excellence in science education?" An attempt has been made to carry out a meta-analytical review of the relevant literature to address some of the issues and concerns for providing laboratory experiences to prospective science teachers. Major issues emerging from the review of literature in this area are- recognizing need and understanding objectives of laboratory work from pedagogical prospective; integrating it with theory and providing laboratory experiences infused with inquiry.
\end{abstract}

Keywords: Prospective science teachers, laboratory experiences, teacher educators, inquiry, science education

\section{Introduction}

Teacher education programmes has very important place in any educational set-up. Prospective science teachers' experiences with laboratory work highly influence their motivation for practicing science in everyday classroom situations. Experiences of laboratory work, feel of apparatus and materials and natural phenomena, events, and working with hands are essential and vital part of science education. Laboratory experiences here mean direct experiences with the natural and physical world using tools and apparatus accompanied by engagement with process and inquiry skills in science. 
Prospective science teachers understanding about laboratory experiences have great implications for teaching-learning of science. Their perceptions of learning and teaching of science influence the way they approach classroom situations and learning needs of the learners. Therefore, they need to be prepared for making laboratory experiences integral part of teaching-learning of science in order to facilitate students to nurture their natural curiosity and engage them towards acquiring proficiency in the processes that can lead them to inquiry and generation and validation of scientific knowledge.

After starting the job, teachers get limited opportunities to enrich their laboratory experiences. Moreover, the inadequacies of prospective teacher education cannot be compensated by in-service education.

Laboratory work is the distinctive feature of science education. Laboratory work helps students to have meaningful understanding about scientific concepts and enhances students' motivation to learn science (Hofstein \& Lunetta 2004; Lunetta, Hofstein \& Clough, 2007). Roth (1994) holds the opinion that although laboratories have long been recognized for their potential to facilitate the learning of science concepts and skills, this potential has yet to be realized.

The first-hand experiences obtained through experimental work imprints a permanent impression on the mind of the learners. The kind of experiences provided by the laboratory work cannot be replaced by any other task. Well-planned laboratory experiences have great potential to attract our young generation into science courses (NCERT, 2013). Creating learning environment that encourages inquiry; engages them with meaningful laboratory experiences is of paramount importance to arouse and sustain their interest in science. Engaged with the laboratory work, prospective science teachers should be given ample opportunities to inquire, participate and practice in a collaborative set up with their peers and teacher educators.

This study is guided by the research question, "what is the status of laboratory experiences for prospective teachers?" and "what is missing in prospective science teachers' preparation programme in order to bring excellence in science education?” In this context, an attempt has been made to carry out a meta-analytical review of the relevant literature to address some of the issues and concerns for providing laboratory experiences to prospective science teachers.

\section{Need of laboratory experiences for prospective science teachers}

Many researchers have recognized and realised the need of laboratory experiences for prospective teachers. Emphasising on the need of laboratory experiences, Hofstein and Lunetta (2004) say that the laboratory has been given a central and distinctive role in science education, and science 
educators have suggested that rich benefits in learning accrue from using laboratory activities. In the context of adding value to physics laboratories for the prospective science teachers, Jarrett et al. (2010) observe that they will be responsible for laying the foundations of understanding of hundreds of students, so the quality of their conceptual understanding is of utmost importance. However, unlike other physicists and chemists, they are increasingly likely to be the most qualified and knowledgeable individuals in their workplace, so any misunderstandings are likely to go unchallenged and be passed on to their students.

Dillon (2008) suggests that improvements to laboratory work practices need to be addressed at teacher education level. In particular, teachers should be trained to identify effectiveness by better understanding of: a) What is learnt; b) What processes consciously go on in students' minds, when putting into operation, procedures and methods as well as developing models and theories. This should lead to an improved image of science and a better motivation for it.

Some researchers have reported that practical work can increase students' sense of ownership of their learning and can increase their motivation (Johnstone and Al-Shuaili, 2001). An ideal science learning environment would be one where students are encouraged to feel like practicing scientist-questioning, investigating, testing, evaluating and constructing explanations in such a way that spirit of inquiry and nature of science pervades in all teaching-learning situations.

If prospective teachers do not get opportunities to design activities, experiments, working models, and projects, they have to face lots of difficulties in managing laboratory experiences for their students. In a study Bektas et al.(2011) found that pre-service (prospective) chemistry teachers could not identify laboratory equipment and did not know their functions appropriately. They suggest that in order to design an effective chemistry instruction, laboratory equipment and their functions should be emphasized in chemistry teacher education programs more deeply. Dung (1989) argues that most biology teachers have come through undergraduate science programs without ever having engaged in research activities. The research experience is important in order to convey to students the true nature of scientific research.

Moreover, learning only to facilitate students perform experiments and activities cannot be of much help in developing inquiry in students. Involving students in planning, designing, improvising, innovating and executing various laboratory works in a manner that it can arouse and sustain their curiosity in natural phenomena, is learnt from practice.

In prospective science teacher education programme, we are not only training prospective science teachers, we also are educating future citizens of 
an increasingly technological world. They need to be trained the way they are expected to teach their students.

\section{Objectives of Laboratory work}

Review of the literature show that many objectives can be achieved by providing laboratory experience to students and the prospective teachers. Shulman and Tamir, in the Second Handbook of Research on Teaching (Travers, ed., 1973) listed five groups of objectives that may be achieved through the use of the laboratory in science classes:

1. skills- manipulative, inquiry, investigative, organizational, communicative

2. concepts- for example, hypothesis, theoretical model, taxonomic category

3. cognitive abilities- critical thinking, problem solving, application, analysis, synthesis

4. understanding the nature of science- scientific enterprise, scientists and how they work, existence of a multiplicity of scientific methods, interrelationships between science and technology and among the various disciplines of science

5. Attitudes- for example, curiosity, interest, risk taking, objectivity, precision, confidence, perseverance, satisfaction, responsibility, consensus, collaboration, and liking science.

Kolb and Kolb (2005) and Sa'nchez and Valca'rcel (1999) hold the view that knowledge of objectives is considered to be the cornerstone for implementing practical work in physics teaching at the school level. Nivalainen et al. (2013) believe that pre service teachers' understanding of the objectives of practical work can most effectively be developed by offering them new and successful experiences of it.

National Research Council (2006) identifies one of the important goals for laboratory experiences in science is increased understanding of the nature of science. Laboratory experiences may help students to understand the values and assumptions inherent in the development and interpretation of scientific knowledge, such as the idea that science is a human endeavor that seeks to understand the material world and those scientific theories, models, and explanations change over time on the basis of new evidences. America's lab Report argues that having only one context for content acquisition (the teacher or the text) works against the goal of understanding the nature of science, for the students tend to see science as an immutable facts dispensed to a passive audience by an authority who knows all (Lemke, 1990, in NRC, 2006). Bransford and Schwartz (2001) observe that learning is also improved when it is taught in multiple contexts. When students encounter the same learning in a variety of instructional contexts, including direct instruction, 
laboratory activities, and discussions, they are more apt to come to a deeper and more complete understanding of it (Bransford and Schwartz, 2001; in NRC 2006).

Textbook of Pedagogy of Science (NCERT, 2013) suggests that use of laboratory must be focused towards achieving the objectives of developing (a) cognitive abilities, i.e. principles and laws discussed in the classroom may precede or follow the laboratory work or it may be carried out during discussion; (b) process skills of science; (c) scientific attitude and (d) understanding nature of science.

Laboratory work helps students to have meaningful understanding about scientific concepts and enhances students’ motivation to learn science (Hofstein \& Lunetta 2004; Lunetta, Hofstein \& Clough, 2007). Lazarowitz \& Tamir (1994) argue that laboratory work can help in addressing alternative concepts of learners. They reason that the scientific discussions held during the laboratory work help to define the misconceptions entertained by the students. Furthermore, laboratory work provides concrete experiences and opportunities for students to face their own misconceptions. Berry, Mulhall, Gunstone and Loughran (1999) suggest that predicting the outcome of experiments increases cognitive engagement. Cox and Junkin III (2002) required their students to make predictions, describe their observations or explain observations and results.

However, in majority of the classes, laboratory work is carried out for verification of scientific laws and theories. According to a research conducted by Kang and Wallace (2005), teachers perceive laboratory work solely as an activity for the purpose of verification.

Prospective teachers should be given opportunities to reflect and enhance their understanding of the objectives of laboratory experiences from pedagogical prospective. They may make their students explicitly clear about the general objectives of the laboratory work and the necessary safety measures to be taken in laboratory work. Working on the laboratory tasks, students should be facilitated to arrive at conclusion on their own and thus recognize the objectives pertaining to a particular activity, experiment or project to relate them with relevant scientific concepts.

Prospective science education programme rarely address laboratory experience to empower them for facilitating laboratory work for students. It should be realized that laboratory work is much more than setting up apparatus, performing experiments prescribed in the syllabus and managing students' records. It includes a wide range of experiences with experiments, activities, demonstrations, projects and improvised apparatus incorporating students' ideas and reflections. How to integrate laboratory work with theoretical aspects of science and textbook material, and how to use these work to lead students to inquiry, are some other important issues. 
To sum up, the need to be proficient in performing the experiments, activities given in the textbooks and their organization in the laboratory or classroom through active involvement of students can be fulfilled if prospective science teachers are empowered to :

- $\quad$ identifying students' learning needs, styles, and contexts for facilitating them to work as per their choice, e.g. choosing alternative experiments and activity;

- Encouraging students to inquire, construct explanations and arguments and evaluate alternative explanations based on the evidences;

- $\quad$ Addressing pedagogical issues pertaining to integration of laboratory experiences with the theoretical concepts and day-to-day life;

- $\quad$ Addressing naïve concepts and misconceptions of students through organization of discrepant events;

- $\quad$ Assessing laboratory experiences;

- $\quad$ setting up the apparatus for the experiments and checking their functionality;

- $\quad$ arranging materials, apparatus and equipment for various laboratory experiences;

- $\quad$ improvising apparatus and experiments as and when required;

- $\quad$ facilitating learners to design and carry out investigatory projects;

- $\quad$ Incorporating ICT in laboratory experiences;

- dealing with logistic issues of laboratory like procurement, storing and maintaining apparatus, equipment and chemicals; maintaining records of apparatus, ensuring safety measures in the laboratory, condemning nonfunctional instruments, and apparatus.

The list of the objectives may further be expanded or its order may be changed depending upon various situations.

These objectives can be achieved only if majority of teachers feel empowered to put them in practice. Laboratory work prepares prospective teachers not only for facilitating their students for experimental work, it contributes to their confidence in handling and improvising various apparatus, enhances their understanding of concepts of science and about nature of science.

\section{Integrating laboratory experiences with theory}

This is one of the major issues. Teachers have to realize that laboratory experiences are integral part of the science education. It is of utmost importance that instead of taking laboratory work in isolation or as add-on experience, it has to be closely integrated with theory. Often, there is a gap of several months between the concepts transacted in the theory and 
experiment carried out on the same concept. There is urgent need of getting rid of this fragmented approach to science education.

Position Paper on teaching of Science (NCERT, 2006) expresses concerns over the gradual decline of practical work and experimentation at secondary and higher secondary stages, even while the concept of activity based teaching is yet to become a living reality in our elementary schools. The often repeated recommendation of integrating experimental work and theory teaching has not been realized because of perceived lack of facilities and trained teachers in most of the schools.

According to the NRC 2006 an integrated laboratory program in a course that is inquiry-based will promote a variety of skills associated with scientific reasoning. These include the ability to:

- $\quad$ identify questions and concepts that guide scientific investigations;

- $\quad$ design and conduct scientific investigations;

- $\quad$ develop and revise scientific explanations and models;

- $\quad$ recognize and analyze alternative explanations and models; and

- $\quad$ make and defend a scientific argument, including writing, reviewing information, using scientific language appropriately, constructing a reasoned argument, and responding to critical comments.

McDermott et al. (2000) observe that most science departments, including physics, do not take into account the needs of prospective elementary and middle school teachers. Guiding students through the complexity and ambiguity of empirical work, including verification work requires deep knowledge of the specific science concepts and science processes involved in such work (Millar, 2004).How to relate laboratory experiences of students with the science concepts, laws, theories and everyday life situations should be learnt and critically discussed in prospective science teacher education programme as many researchers (Aufschnaiter \& Aufschnaiter, 2007; Domin, 2007; Mestre, 2001) have reported that the most frequently cited problems with student learning in science and physics laboratories are lack of meaningful discussion and engagement, with students focusing on completing a list of tasks without necessarily understanding them; and failure to link experimental practice to underlying theory and concepts.

\section{Laboratory work for inquiry or for exercise?}

Performing experiments with a spirit of inquiry and thinking critically about various aspects of the material and apparatus as well as concepts of the experiment can lead students towards meaningful understanding of science. Providing ample opportunities to engage students in investigations in search of their own questions and solution of their own identified problems, through discussion with their teachers, peer groups and 
interaction with various learning resources is important. Therefore, all stakeholders involved in science education programme need to appreciate that only hands-on experience, without minds-on experience, laboratory work has little pedagogical value. Laboratory experiences need to be structured in a manner that can encourage students to question, critically review, construct explanation and evaluate alternative explanations of the work.

Inquiry-type laboratories have the potential to develop students' abilities and skills such as: posing scientifically oriented questions (Krajcik et al., 2001; Hofstein et al., 2005), forming hypotheses, designing and conducting scientific investigations, formulating and revising scientific explanations, and communicating and defending scientific arguments. Hodson (1993) emphasized that the principal focus of laboratory activities should not be limited to learning specific scientific methods or particular laboratory techniques; instead, students in the laboratory should use the methods and procedures of science to investigate phenomena, solve problems, and pursue inquiry and interests.

Collaborative set up in teaching-learning situation of science fosters inquiry in students. Such set up provides opportunities to generate multiple ideas for discussion and inquiry. Researches has shown that learning is enhanced in a community setting, when students and teachers share norms that value knowledge and participation (Cobb et al., 2001). In collaborative settings students get immediate feedback and motivation, compare their observations and findings with each other. Lazarowitz \& Tamir (1994) observe that the scientific discussions held during the laboratory work help to define the misconceptions entertained by the students. Furthermore, laboratory work provides concrete experiences and opportunities for students to face their own misconceptions.

Ünal and Özdemir (2013) argue that Students need to be able to arrive at an understanding of why they do, what they do, and to construct feasible explanations for their experiences, instead of completing a set of prescribed steps presented by another individual.

In order to provide the prospective science teachers sufficient time to initiate, discuss, plan, and carry out various experimental work, block periods can be arranged. Teacher educator should empower them to use and improvise various apparatus as per the needs of activities and experiments and available materials; design innovative projects incorporating their critical review and reflection, and manage the laboratory experiences through collaborative inquiry approach. 


\section{Current status of the laboratory work}

Present review of the literature shows that laboratory work in science at many places is being carried out as exercise without engaging students in inquiry. The studies under review also express concern over the current status of laboratory experiences for students and prospective teachers. Kirschner (1992) says, "Years of efforts have produced 'foolproof' experiments when the right answer is certain to emerge for everyone in the class if laboratory instructions are followed.” Typical laboratory experiences appear to have little effect on more complex aspects of scientific reasoning, such as the capacity to formulate research questions, design experiments, draw conclusions from observational data, and make inferences (Klopfer, 1990, cited in White, 1996).

As Beisenherz \& Dantonio (1991) state " . . . teachers cannot be lectured at, demonstrated to, and asked to regurgitate facts in course after course, semester after semester, and then be expected to teach the processes of science without having experienced them". McDermott et al. (2000) observe, the laboratory courses offered by most physics departments also do not address the needs of teachers. Often the equipment is not available in high schools, and no provision is made for showing teachers how to plan laboratory experiences that utilize simple apparatus. A more serious shortcoming is that experiments are mostly limited to the verification of known principles. Students have little opportunity to start from their observations and go through the reasoning involved in formulating these principles. As a result, it is possible to complete a laboratory course without confronting conceptual issues or understanding the scientific processes.

As Alexis Pokrovsky of UNESCO(cited in Schneegans,2003)puts it, 'How can any country train scientists, let alone promote the national research which is indispensable to development, without experimentation? Even the most practical notions appear abstract to a student who can't put theory into practice. And nothing compensates for the solid grounding in biology, physics and chemistry which experimentation provides. Yet the reality of science teaching is still far from satisfactory', Pokrovsky notes. 'Little or no practical activity is available in many school classrooms and university laboratories. This is particularly so in the developing countries but even in wealthy countries you find virtual substitutes for laboratory experiments, such as computer-based simulations and video sequences. In poor countries, science teachers often have no more than a blackboard to work with.

Ünal and Özdemir (2013) found that in general, laboratories are exercises with a primary focus on the verification of established laws and principles, or on the discovery of objectively knowable facts. In laboratories, students gather data without comprehending the meaning of their actions. The cognitive demand of laboratory tasks is reduced to a minimal level. 
Similar findings are reported by Prabha (2013). She visited thirty five schools spread over eight States in India to observe how the laboratory work in Physics is carried out at Higher Secondary Stage (class 11-12).

Cossa, E.F.R. and Uamusse A.A. (2015) in their study in Mozambique observed that teachers complained about the length of the Biology and Chemistry syllabuses and recommend a thorough revision if the Ministry of Education wants them to conduct laboratory work in their classes and hence, comply with its aims. The fact that most of the teachers during their initial training did not have laboratory work effectively resulted in the fragility and fear to use any kind of laboratory work.

Students are provided a limited range of laboratory experiences as teachers themselves do not have training for this. Once they start doing job, they have very limited opportunities to acquire proficiency in carrying out laboratory work through integration with theory and incorporation of discussion and inquiry. Asking/framing scientifically testable questions, forming hypothesis, planning investigations, using tools and apparatus, making observations, constructing explanation, evaluating alternative explanations and revisiting the observations in the light of new explanations, arriving at conclusion and justifying and communicating the findings with appropriate evidences are part of laboratory experiences.

Mostly, laboratory work is carried out as ritual work. Most students verify the established scientific knowledge. Generally steps of procedures only are emphasized. Students ask typically procedural questions, rarely discuss conceptual issues. They are rarely provided opportunities for framing scientifically testable questions and engaging in investigations and inquiry in search of their own questions. A prescribed number of experiments are carried out mechanically. Classes are crowded, teachers are overburdened. Students perform experiments and note down the observations without critically thinking why they are using a particular apparatus, a particular method and in some cases they are not even aware with the objective of the experiment. Assessment of laboratory work is another major concern of science education. Whether it is internal or external examination, students are given inflated marks. Ottander and Grelsson (2006) have emphasized that when certain laboratory work is being planned, the goals, instructions and the assessment criteria should be considered holistically.

Duggan, Johnson, and Gott (1996) described the structure of science as substantive and syntactical. The substantive element of conceptual understanding included facts, concepts, laws, theories, and principles. Those were the elements presented in lecture-type science courses. On the other hand, the syntactical structure included the procedural understanding gained from skills and the concepts of evidence. In the context of the latter part Melear (1999) argues that syntactical structure is missing from the 
systematic preparation of science teachers. Currently, pre-service science teachers are not expected to design experiments or to present evidentiary arguments, as real scientists do, in a systematic way as a part of their teacher preparation. How then can we expect them to teach K-12 students when they themselves have not experienced these skills and concepts of evidence? Hodson (1993) asserted that "the only effective way to learn to do science is by doing science, alongside a skilled and experienced practitioner who can provide on-the-job support, criticism and advice”. Beisenherz \& Dantonio (1991) state that “ ... teachers cannot be lectured at, demonstrated to, and asked to regurgitate facts in course after course, semester after semester ,and then be expected to teach the processes of science without having experienced them".

The studies referred above reflect that the current status of laboratory experience of prospective science teacher is a matter of grave concern.

\section{Conclusion}

It is found that all researchers under this study have expressed their concern for the current status of laboratory work for the prospective science teachers. Major issues emerging from the review of literature in this area are-recognizing need and understanding objectives of laboratory work from pedagogical prospective; integrating it with theory and providing laboratory experiences infused with inquiry. In the light of qualitative review of the literature, it is suggested that in our efforts to bring excellence in science education, professional development programme of prospective science teachers should be restructured in such a way that it can empower them to engage students in laboratory work by fostering sprit of inquiry in them.

It is important for the science teacher educators to recognize that prospective science teachers must be better equipped to meet the challenges of facilitating students' construction of scientific knowledge through direct experience of managing and setting up laboratory work and engagement in inquiry. Prospective teachers should be made conversant in integrating laboratory work seamlessly with teaching-learning and infusing with scientific inquiry. This can provide the missing link to excellence in science education. Teacher educators' experiences with laboratory work at various stages of school education are a major concern. They should have a certain minimum experience of teaching science in schools so that they can facilitate prospective science teachers to design learning experiences integrated with a range of laboratory experiences infused with inquiry. This can motivate students to develop interest in science and take up science course in future. Various programmes for capacity building for the teacher educators need to be arranged. Workable techniques of assessment need to be devised for the assessment of laboratory work for effective teaching-learning of science. 
The conclusion drawn from this meta-analytical review supports the suggestion of Akarsu (2015) that teacher candidates should be trained better in their laboratory courses in teacher preparation programs. Also, it will be a good idea to revise method courses to be more inclined to include more application activities. Position paper on teaching of science (NCERT, 2006) envisions a complete overhaul of the teacher education system in the country, including modernization of syllabus, development of appropriate laboratories for teacher education in science and a vigorous recruitment of high quality teacher educators.

It goes without saying that the teacher should herself be competent in the area she teaches; she must be familiar with all the aspects of the nature of science; she must have imbibed scientific attitude and spirit of scientific inquiry herself. She can then help her students to retain and further sharpen their sense of inquiry by allowing them to explore their environment and encouraging to ask questions even if sometimes these questions appear trivial, and engaging them in argumentation, supported by evidences and reasoning. By her own enthusiasm for science she can induce the excitement of doing science among students.

And above all, prospective teachers also need to be convinced with the idea that engaging students with the laboratory work and scientific inquiry will make their work easier, i.e. students will learn easily. They should shun away the notion that they would not be able to cover the syllabus, if laboratory work is carried out. Rather, it can provide the teachers with the opportunity to uncover the existing ideas of students that can help them to understand students understanding. Unless prospective teachers realise the need and importance of laboratory experiences in teachinglearning of science, they would neither get convinced nor develop confidence for facilitating such experiences for students.

We need to bring major overhaul in prospective science teacher preparation programme in our effort to achieve excellence in science education.

\section{References:}

1. Akarsu, B. (2015). Pre-Service Teachers' Attitudes Towards Lab Applications in Science Teaching, Journal of European Education, 5(2), 56-61.

2. Aufschnaiter, C., \& Aufschnaiter, S. (2007). University students' activities, thinking and learning during laboratory work. European Journal of Physics, 28, 51-60.

3. Beisenherz, P.C. \& Dantonio, M. (1991). Preparing secondary teachers to study science teaching, Journal of Science Teacher Education, 2(2), 40-44. 
4. Bransford, J.D., and Schwartz, D.L. (2001). Rethinking transfer: A simple proposal with multiple implications. In A. Iran-Nejad, and P.D. Pearson (Eds.), Review of research in education (pp. 61-100). Washington, DC: American Educational Research Association.

5. Bektas et al. (2011). Pre-service chemistry teachers' knowledge regarding laboratory equipment and their functions, Procedia Social and Behavioral Sciences 15, 510-514.

6. Berry, A., Mulhall, P., Gunstone, R., \& Loughran, J. (1999). Helping Students Learn from Laboratory Work. Australian Science Teachers' Journal, 45(1), 27-31.

7. Cox, A. J., \& Junkin III, W. F. (2002). Enhanced student learning in the introductory physics laboratory. Physics Education, 37(1), 37-44.

8. Cezmi Ünal and Ömer Faruk Özdemir. (2013). A physics laboratory course designed using problem-based learning for prospective physics teachers European Journal of Science and Mathematics Education, 29-33.

9. Cobb, P., Stephan, M., McClain, K., and Gavemeijer, K. (2001). Participating in classroom mathematical practices, Journal of the Learning Sciences, 10,113-164.

10. Cossa, E.F.R. and Uamusse A.A. (2015). Effects of an In-service Program on Biology and Chemistry Teachers' Perception of the Role of Laboratory Work Procedia - Social and Behavioral Sciences 167, $152-160$

11. Dillon, Justin. (2008). A Review of the Research on Practical Work in School Science (p.62). http:/ www.scoreeducation.org/media/3671/review_of_research.pdf July10, 2016.

12. Domin, D. S. (2007). Students' perceptions of when conceptual development occurs during laboratory instruction. Chemistry Education Research and Practice, 8(2), 140-152.

13. Dung, Patricia C. Biology Teacher Training: Preparing Students for Tomorrow) In High- School Biology Today and Tomorrow Rosen, W.G.(ed), National Academic Press, Washington D,C. education (pp. 392-441). Mahwah, NJ: Erlbaum.

14. Duggan, S., Johnson, P., \& Gott R. (1996). A critical point in investigative work: Defining variables. Journal of research in science teaching, 33,461-474.

15. Hodson, D. (1993). Re-thinking old ways: Towards a more critical approach to practical work in school science. Studies in Science Education, 22,85-142. 
16. Hofstein, A., \& Lunetta, V. N. (2004). The laboratory in science education: Foundations for the twenty-first century. Science Education, 88, 28-54

17. Hofstein A., Navon O., Kipnis M. and Mamlok-Naaman R. (2005). Developing students' ability to ask more and better questions resulting from inquiry-type chemistry laboratories, Journal of Research in Science Teaching, 42, 791-806.

18. Jarrett, L, Takacs, GJ and Ferry, B. (2010). Adding value to physics laboratories for pre-service teachers, International Journal of Innovation in Science and Mathematics Education, 18(1), 26-42.

19. Johnstone, A. H. and Al-Shualili, A. (2001). Learning in the laboratory; some thoughts from the literature, University Chemical Education, 5, 42-50.

20. Kang, N.H. \& Wallace, C.S. (2005). Secondary science teachers' use of laboratory activities: Linking epistemological beliefs, goals, and practices. Science Education, 89(1), 140-165.

21. Kirschner, P. (1992). Epistomology, practical work and academic skills in science education, Science Education, 1,273-299.

22. Klopfer,LE.(1990). Learning scientific enquiry in the student laboratory. In E. Hegarty -Hazel (Ed.), The student laboratory and the science curriculum (pp.95-118). London, England:Routledge.

23. Kolb, A.Y. and Kolb, D. A. (2005). Learning styles and learning spaces: Enhancing experiential learning in higher education, Academy of Management Learning \& Education, 4, 193.

24. Krajcik J., Mamlok R. and Hug B. (2001). Modern content and the enterprise of science: science education in the 20th century. In: L. Corno (Ed.). Education across a century: the centennial volume (pp. 205-238). Chicago, Illinois: National Society for the Study of Education (NSSE).

25. Lazarowitz, R. \& Tamir, P. (1994). Research on using laboratory instruction in science. In D.L. Gabel (Ed.), Handbook of research on science teaching and learning (pp. 94-128). New York: Macmillan.

26. Lemke, J. (1990). Talking science: Language, learning, and values. Norwood, NJ: Ablex.

27. Lunetta, V. N., Hofstein, A., \& Clough, M. P. (2007). Learning and teaching in the school science laboratory: An analysis of research, theory, and practice. In S. K. Abell \& N. G. Lederman (Eds.), Handbook of research on science education (pp. 392-441). Mahwah, NJ: Erlbaum.

28. McDermott, L. C., \& Shaffer P., S. and Constantinou, C.P. (2000). Preparing Teachers to Teach Physics and Physical Science by Inquiry, Physics Education 35(6), pp411-416 . 
29. Melear C.,T. (1999). Middle and secondary science teacher opinions about working in scientists laboratories during pre service preparation, Electronic Journal of Science Education,4(2).1-7.

30. Mestre, J. P. (2001). Implications of research on learning for the education of prospective science and physics teachers. Physics Education, 36(1), 44-51.

31. Millar, R. (2004). The role of practical work in the teaching and learning of science. Paper prepared for the Committee on High School Science Laboratories: Role and Vision. National Academy of Sciences, Washington DC. York: University of York.

32. National Research Council. (2006). America's Lab Report: Investigations in High School Science. Committee on High School Science Laboratories: Role and Vision, S.R. Singer, M.L. Hilton, and H.A. Schweingruber, Editors. Board on Science Education, Centre for Education. Division of Behavioral and Social Sciences and Education. Washington, DC: The National Academies Press. pp75113.

33. NCERT. (2006). Position paper of national focus group on teaching of science. New Delhi: National Council of Educational Research and Training.

34. NCERT. (2013). Pedagogy of science: Physical science, Textbook for B.Ed (pp 279-283). New Delhi: National Council of Educational Research and Training.

35. Nivalainen, V., Asikainen, M.A. and Hirvonen P.E. (2013). Pre service Teachers' objectives and their experience of practical work Physics . Review Special-Topics, Physics Education . Research. 9, 117

36. Ottander, C. \& Grelsson, G. (2006). Laboratory work: the teachers' perspective. Journal of Biological Education, 40(3), 113-118.

37. Prabha, S. (2013). A study of physics curriculum at higher secondary stage. Unpublished project report. New Delhi: National Council of educational Research and Training.

38. Roth, W. M. (1994). Experimenting in a constructivist high school physics laboratory. Journal of Research in Science Teaching, 31, 197-223.

39. Sa'nchez G. and Valca'rcel, M.V. (1999). Science teachers' views and practices in planning for teaching, Journal of Research in Science Teaching, 36, 493.

40. Schneegans, Susan. (2003). Practical laboratory work - To be or not to be? A World of SCIENCE, 1(2), 14-15. 
41. Shulman, L.S. and Tamir, P. (1973). In Travers, Robert M. W. (1973). Second Handbook of Research on Teaching. Chicago: Rand McNally \& Co.

42. Tobin, K. G. (1990). Research on science laboratory activities. In pursuit of better questions and answers to improve learning. School Science and Mathematics, 90, 403-418.

43. Ünal C. and Özdemir, O.F. (2013). A physics laboratory course designed using problem-based learning for prospective physics teachers European Journal of Science and Mathematics Education 1(1), 29-33.

44. White, R.T. (1996). The link between the laboratory and learning. International Journal of Science Education, 18, 761-774. 